\title{
Brexit and the Differentiated European (Dis)Integration
}

\section{Angélica Szucko*}

\begin{abstract}
On 25 March 2017, the European Union celebrated the $60^{\text {th }}$ anniversary of the Treaties of Rome, which established 'an ever-closer union' as a fundamental principle for European regional integration. Only four days later, the United Kingdom delivered an official letter triggering its withdrawal process from the Community. How could we comprehend Brexit integrative and disintegrative dynamics to the EU? The UK's decision to leave the EU alongside recent crises in the Community and the spread of Eurosceptic movements fostered studies about disintegration dynamics. This article presents the current debate about differentiated (dis)integration based on up-to-date related literature. Next, it proposes a framework to assess the recent shifts in the UK-EU relationship and its contradictory effects on the EU project. The main argument of the paper is that the UK's relationship with the European Union moved from an internal differentiated integration to a proposal of internal differentiated disintegration and, thereafter, to a process of external differentiated disintegration. Moreover, although Brexit means disintegration by one Member State, its effects on the EU project are mixed, initially promoting an integrative boom among the EU27 members, while at the same time neglecting disintegrating forces that could undermine the traditional European integration model.
\end{abstract}

Keywords: European Union; Brexit; differentiated integration; differentiated disintegration; European integration.

\section{Introduction}

European integration is widely pointed out as the most advanced experience in terms of collective action strategies and, therefore, serves as a model for studies on regionalism and interstate cooperation. Unlike other regional blocs, the European process goes beyond economic and trade cooperation and consists of a much more comprehensive integration, coming closer to a political union rather than to a merely intergovernmental economic bloc. Although Europe is a continent historically marked by wars and numerous clashes and characterized by enormous cultural diversity, European unification suggests that cooperation around common goals is possible (Costa 2017). The treaties and agreements

\footnotetext{
* University of Brasília (UnB), Brasília-DF, Brazil; angelicaszucko@gmail.com. ORCID iD 0000-0002-85897827.
} 
concluded between the Member States of the European Union comprise a framework of more than 80000 pages of legislation, setting the acquis communautaire, ${ }^{1}$ which regulates the interaction between national and European institutions and their responsibilities, rights and duties on several subjects.

Usually, explanations for the framing of European communities are called integration theories and are based on the assumption of a constantly enhanced cooperation with hiatus of stagnation (Börzel and Risse 2018). Since the foundation of the European Economic Community (ECC) in 1957, the construction of 'an ever-closer union'2 (Treaty of Rome 1957:1) was fixed as a fundamental principle of the regional integration process. However, during the phases of deepening integration, some Member States have been granted optouts and do not participate in certain European policy areas, characterizing a process of internal differentiation. In a nutshell, 'differentiation is a legal exemption from the validity of the rules that govern a policy area' (Winzen and Schimmelfennig 2016: 9).

Even though concepts such as 'spill-back' were forged to explain step back moments, still few scholars actively engage in studies about disintegration dynamics. According to neo-functionalists, 'spill-back' relates to 'the process when a Member State becomes less willing to support European regulation of certain policy issues' (Vollaard 2014: 3). It entails the withdrawal from pieces of the Community's obligations and the assumptions that both loyalties and competences would move back from European authority to national states (Vollaard 2014).

Indeed, European Studies have mainly focused efforts on trying to explain why States cooperate and seek regional integration while so far neglecting the possibility of EU disintegration. The construction of the European Communities is normally described in a range of more or less integration, but not disintegration.

The dependent variable can take several values, which can be placed on a continuum whose opposite ends seem to be integration vs. no integration, stagnation, or 'encapsulation' rather than disintegration. Likewise, changes usually are analyzed in terms of more integration vs. stagnation (Börzel and Risse 2018: 5).

The $21^{\text {st }}$ century brought new challenges to the European Union, which has been facing several crises, such as the effects of the 2008 global financial crisis - in particular in the Eurozone countries - as well as the growth in the flow of immigrants and the increase in the number of asylum seekers and the expansion of nationalist and Eurosceptic movements and parties both in the national states and within the European Parliament. In addition, since 2016, the EU has been dealing with the United Kingdom's withdrawal process (Schnapper 2017; Schimmelfennig 2018a).

In short, these crises contribute to rethinking both the European Union's project and the future of its integration process. It is worth remembering that the Community had already faced severe crises before. Indeed, as pointed out by Robert Schuman (1950), 'Europe will not be made all at once, or according to a single plan.' The crises forged the $\mathrm{EU}$ as it is. From the late 1960s until the early 1980s, for example, the bloc underwent a 
period of intense problems, such as the French chaise vide ${ }^{3}$ policy and the adjustments to new enlargements. After that, the agreement on the Single European Act represented a major step for regional integration and the UK acted as a key driver promoting the Single Market project (George 1998). The difference from the previous crises to the current one is that while previous crises correspond to moments of stagnation in the European integration, the current crisis leads to a disintegration process by one Member State: the United Kingdom, exemplified by Brexit.

Before the Brexit referendum, disintegration theories were not granted much room for discussion inside EU institutions and among EU scholars. Yet from Brexit on, it seems that disintegration approaches have been gaining ground as a means to account for this unprecedented process, namely the first time that a Member State decided to leave the European community. ${ }^{4}$ Now, even the European Commission has been considering alternatives of less integration ${ }^{5}$ in its 'White Paper on the Future of Europe: reflections and scenarios for the EU27 by 2025' published in March 2017, ironically, at the same period of time as the commemoration of the sixtieth anniversary of the Treaties of Rome.

Considering the troubled European context, this article intends to answer the following research question: How could we comprehend Brexit integrative and disintegrative dynamics to the EU? This work aims to discuss concepts such as differentiated integration/disintegration and present a framework to analyze the recent shifts in the UK-EU relationship. In order to meet this objective, the paper is divided in three sections. Firstly, based on the up-to-date literature on European integration, the integration-disintegration spectrum is discussed, and an analysis framework to combine it with standard and exceptional cases is presented considering the concepts of internal/external differentiated integration/disintegration. Secondly, the (dis)integration framework is used to understand the transformations of Britain's relationship with the European Union since the 2015 national elections in the UK. Finally, based on official EU documents, the integrative and disintegrative effects of Brexit to the EU project are analyzed considering its paradoxes. This paper takes on a political-institutional rather than an economic approach, considering the European Union as a unit of analysis as well as its Member States, particularly the United Kingdom. In this sense, the article is not mainly about Brexit but rather about processes and theories of differentiated (dis)integration, using the UK withdrawal as a case study. In addition, it follows a methodology of content analysis, with a special focus on the official documents from the UK government and the institutions of the European Union. This work joins efforts to study the EU through non-mainstream perspectives, and its major contribution is to suggest alternative ways of grasping the (dis)integrative dynamics of Brexit with regard to the EU.

\section{Theoretical framework: differentiated integration vs differentiated disintegration}

As a result of the rising Euroscepticism across Europe, the specter of disintegration has been haunting the European Union (Vollaard 2014). Although an updated literature on 
the subject has been gaining ground in the past few years (Webber 2013; Vollaard 2014; Cianciara 2015; Rosamond 2016, 2019; Schnapper 2017; Jones 2018; Schimmelfennig 2018a; Leruth, Gänzle and Trondal 2019), Jan Zielonka (2014: 22) argued that 'the problem is that EU experts have written a lot about the rise of the EU, but virtually nothing about its possible downfall.' According to that remark, EU scholars could make the same mistake as Sovietologists and be unable to predict a possible break-up of the European Union. What explains this shortcoming of disintegrative approaches?

First of all, the major reason that contributed to the rise of European studies on regional integration was precisely the formation of the European communities in the 1950s. Thus, perhaps the fear of disintegration with the looming United Kingdom's withdrawal from the EU will bring new opportunities to theorize about the issue. Indeed, the mainstream integration theories were developed in parallel to the deepening and widening of the European integration process to account for changes in regional interstate relationships.

On the one hand, Ernst Haas's book The Uniting of Europe, a landmark of neo-functionalist theory, was first published in 1958 to reflect advances of the European integration through a spill-over process between 1950 and 1957. In 1951, the Treaty of Paris established the European Coal and Steel Community (ECSC), while in 1957, the Treaties of Rome had created the European Economic Community (ECC) as well as the European Atomic Energy Community (Euratom). On the other hand, the emergence of the intergovernmental perspective followed the chaise vide crisis and reiterated the primary role of the States and their governmental preferences in the integration process.

Another explanation for the fact that there are few studies regarding disintegration is the institutionalist bias of those mainstream integration theories (Rosamond 2016), but also due to the way IR or political science and political sociology framed the issue. These disciplines and their theories did not grant much importance to institutional crisis and inertia; institutions were seen as incremental and adaptive processes. Both neo-functionalism and intergovernmentalism, as major integration perspectives, believe that institutions are pretty resilient and may face moments of stagnation, but not disintegration. The institutional inertia of the regional integration process was usually considered a benchmark of path dependence. According to James Mahoney (2001: 111), 'path dependence occurs when the choices of key actors at critical juncture points lead to the formation of institutions that have self-reproducing properties.' In other words, once a path is chosen, it is really hard to go back and change it. In this vein, 'the suggestion was that integration would have limits rather than that it would unravel' (Rosamond 2016: 866).

Also, as pointed out by Rosamond (2016), the disintegration analysis suffers from the 'dependent variable problem.' Is the disintegration a process or an outcome? What does disintegration exactly mean? Does it imply going back to the sovereign states' status or to any setback to the current phase of integration? For this study, we will consider disintegration as a setback, because in a globalized and interdependent world, it is almost impossible to imagine sovereign states according to the classical Westphalian concept. The reason for this is that states participate in many international institutions and are bound 
by international rules and regimes. In addition, we must differentiate the disintegration by one EU Member State from the disintegration of the European Union. Whereas the latter corresponds to a general setback in the whole integration process, the former means regaining powers from the EU level to a specific national State, which might unleash both integrative and/or disintegrative dynamics to the EU project, as the Brexit example highlights in the third section of this article.

Moreover, it is important to distinguish disintegration and opt-outs from integration. While the first means a step back from the current status quo of the integration, the second refers to a differentiation process in which some states decided not to move forward into a deep integration, but also did not return to a previous integration that had formerly taken place. Setbacks in relation to an integration already achieved can be seen as a process of disintegration, be it uniform - when applied to all Member States - or differentiated. In other words, it means a return of competences and powers from the EU to the national level. Thus, it is not a specific outcome, but a relative position. In sum, disintegration should be studied as an open-ended process rather than a pre-defined outcome:

[I]t is more politically urgent and analytically plausible to think about disintegration as an indeterminate process and thus how disintegrative forces and dynamics might transform significantly the EU institutional equilibrium, whilst simultaneously being constrained and shaped by it (Rosamond 2016: 868).

Centripetal and centrifugal forces are always interacting to shape the EU integration process. When centripetal forces surpass the centrifugal ones, an integrative momentum flourishes. Conversely, disintegration claims usually emerge when centrifugal forces exceed centripetal ones. According to Erick Jones (2018: 442), 'integration is a process that brings things closer together in some respects; it has a kind of reinforcing momentum or feedback loop [...], and yet that momentum or feedback tends to exhaustion. In that sense, both integration and disintegration processes should be seen as a cumulative causal model of centripetal and centrifugal forces that frame the institutional developments of the EU. Sometimes it will strengthen integration dynamics, and sometimes it will open space for countervailing disintegration movements. While interstate interdependence itself works as a centripetal force and a driver for more integration, the level of politicization, depending on the interdependence context, might function as a centrifugal force and an obstacle for further standard integration outcomes.

If interdependence is low, politicization does not matter much because there will not be major demand for substantial integration in the first place. If strong interdependence is combined with no or weak politicization, demand for integration is likely to be met. If strong interdependence is confronted with strong politicization, however, integration will fail, remain at a low level, or become differentiated (Schimmelfennig, Leuffen and Rittberger 2015: 9). 
The combination of these two variables - interdependence and politicization - contributes to vertical (deepening) and horizontal (widening) differentiated integration inside the EU's system. Peter de Wilde (2011: 560) defines politicization of the European integration 'as an increase in polarization of opinions, interests or values and the extent to which they are publicly advanced towards the process of policy formulation within the EU.' However, it is a limited definition. 'Politicization in general terms means the demand for or the act of transporting an issue into the field of politics' (Zürn 2014: 50). It is observed when a decision regarding an issue seems to be open for public discussion. In a more detailed approach, Zürn (2014) states that politicization can be operationalized by three indicators: awareness, mobilization and contestation. The first two indicate the level of interest in, and engagement with, an issue and alone do not engender centrifugal forces. However, the degree of contestation ${ }^{6}-$ defined as social practices of objection to specific issues (Wiener 2017: 112) - may hamper integration. In this vein, when the degree of contestation in a politicized issue is higher, further integration may not occur or become differentiated. Denmark, for example, was granted integration opt-outs by the EU in a process of accommodation after the Maastricht Treaty was rejected by a national referendum in 1992.

As discussed above, integration theories have advanced alongside European integration history. Moreover, after the Treaty of Maastricht, as differentiation practices increased in the EU, there has been a proliferation of explanations for differentiated integration (Stubb 1996; Holzinger and Schimmelfennig 2012; Leuffen, Rittberger and Schimmelfennig 2013; Cianciara 2014; Leruth and Lord 2015; Schimmelfennig, Leuffen and Rittberger 2015; Chopin and Lequesne 2016; Schimmelfennig 2016; Winzen and Schimmelfennig 2016; Cianciara and Szymański 2019).

In fact, whereas EU competences have grown, the differentiation process has become more common, rendering the Community less uniform. The deepening and widening process of the EU's authority and functional and territorial growth, as a result of the increase of its supranational powers and several enlargements, have been accompanied by a process of differentiated integration (Schimmelfennig, Leuffen and Rittberger 2015; Winzen and Schimmelfennig 2016). Stubb (1996) and Schimmelfennig (2016) point out a slew of taxonomies used by the literature to describe both EU variable membership and variable centralization of integrated policies. For example, 'multi-speed Europe,' 'variable geometry,' 'Europe à la carte' and, finally, 'system of differentiated integration.' According to Frank Schimmelfennig (2016: 6), 'graded membership is an - often unintended - outcome of international disagreement about proposals to deepen or widen European integration, both for EU Members and Non-Members States. To sum up, differentiated integration provides alternative paths to accommodate incompatible or heterogeneous states' preferences regarding the integration process.

In this vein, just as the integration process, the disintegration process interacts at different levels of aggregation, which contributes to the definitions of internal/external, differentiated/uniform integration/disintegration (Figure 1). Whereas integration means a process of deeper cooperation through common rules and institutions, disintegration 
refers to any setback concerning a degree of integration already achieved. All in all, 'integration refers to an increase - and disintegration to a reduction - in the centralization level, policy scope, and membership of the EU' (Schimmelfennig 2018a: 3; Leuffen, Rittberger and Schimmelfennig 2013: 8).

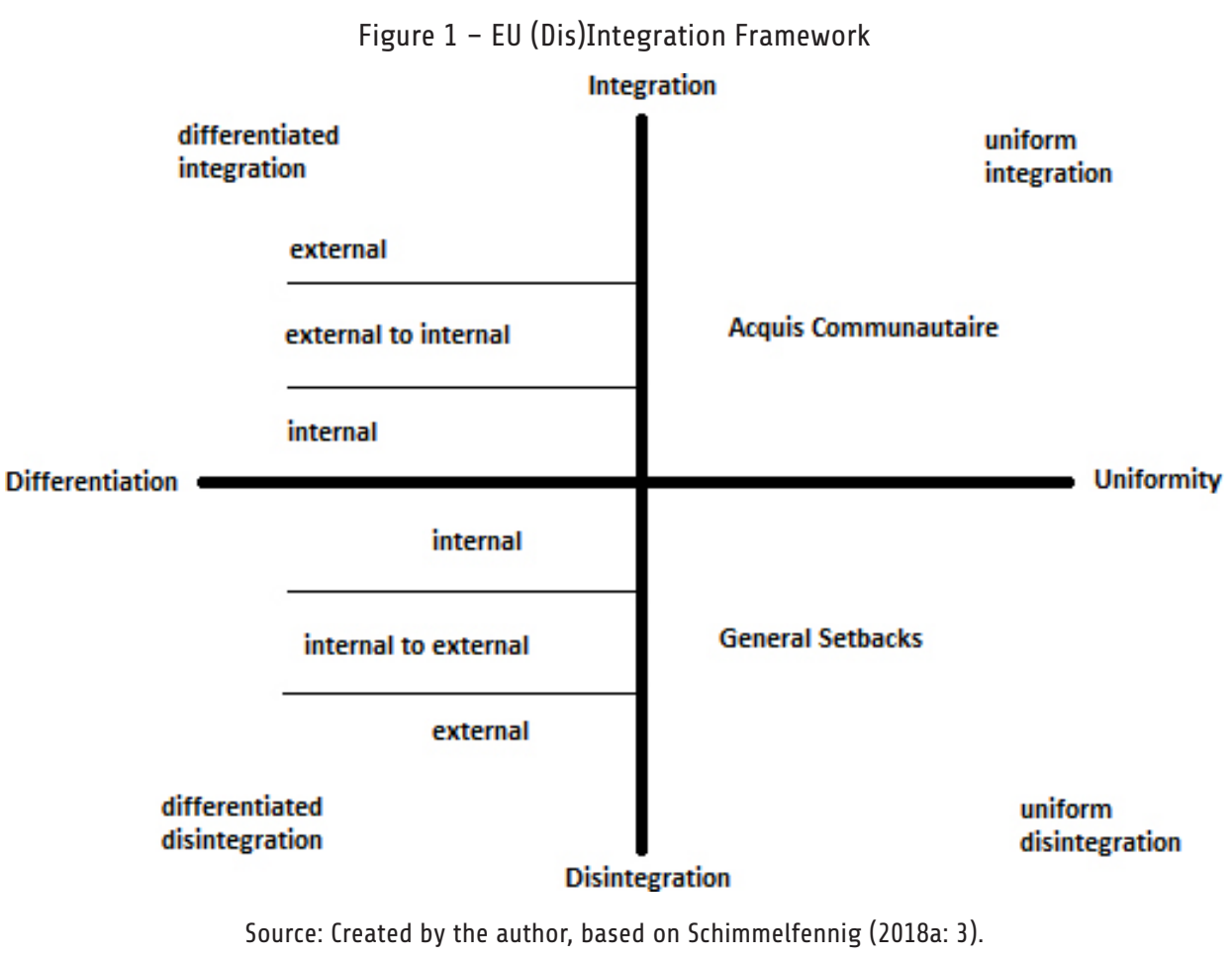

Figure 1 exemplifies the framework, proposed by Frank Schimmelfennig (2018a), portraying the intersection between the vertical axis that corresponds to the integration/ disintegration spectrum and the horizontal axis which refers to standard (uniformity) and exceptional (differentiation) cases. The upper-right quadrant represents the initiatives related to a uniform integration standardized by the acquis communautaire, that is, the cumulative community legislation that should be absorbed by all EU countries. Although the Member States are not still in the same degree of integration, they should reach this objective, ideally and eventually, in a future time, according to treaties' provisions. As pointed out by Winzen and Schimmelfennig (2016: 1), 'a uniform level of integration across all member states can still be considered the standard and proclaimed goal of [the European institutions during negotiations both for revisions on its treaties and accession of candidates to membership].

The upper-left quadrant presents the current cases of formal arrangements in the EU primary law of differentiated integration. During the European Union's institutional 
consolidation phase, differentiated integration was used as a tool to adjust heterogeneity by conceding regulation exceptions to the acquis communautaire. As proposed by this paper, as an extension of Schimmelfennig's work and based on the literature on the subject, it can also be expressed in three different ways: 1 . internal differentiated integration; 2 . external to internal differentiated integration; and 3. external differentiated integration.

The first, internal differentiated integration, corresponds to the opt-outs granted to some Member States with the purpose of continuing the deepening process among the Union avoiding the obstruction of those who are not interested in joining all further integrative steps and which had insurmountable sovereignty issues. Currently, the optouts held by EU countries are the following: a. Denmark and the United Kingdom, from the European Monetary Union; b. Ireland and the United Kingdom, from the Schengen Agreement; c. Poland and the United Kingdom, from the Charter of Fundamental Rights of the European Union; d. Denmark, Ireland and the United Kingdom, from the Area of Freedom, Security, and Justice; and e. Denmark, from the EU's Common Security and Defense Policy. With the signing of the Maastricht and Amsterdam Treaties, in 1992 and 1997, respectively, the European Monetary Union and the Schengen Area have been incorporated into the acquis communautaire, and all countries that have joined the Community later have had to comply with them as soon as the minimum criteria have been met.

The second, external to internal differentiated integration, relates to the exemptions and transitional periods negotiated during the accession process of new Member States which do not comply yet with all the community legislation, as, for example, the fact that Bulgaria, Croatia ${ }^{7}$ Cyprus and Romania are not in the Schengen Area. Also, Bulgaria, Croatia, the Czech Republic, Hungary, Poland, Romania and Sweden are not in the Eurozone (European Union 2019). It is noteworthy that all those countries joined the EU after the Maastricht Treaty, which had already incorporated the EMU to the EU legislation, so they were not able to require an opt-out. Even though it is supposed to be a transitional period, the flexibility regarding the criteria fulfillment has prolonged this external to internal differentiated integration to a semi-permanent status, particularly in the case of Sweden.

Sweden has been managing not to adopt the Euro since its implementation in 1999, despite the fact that it does not have an official opt-out granted by the EU. Even though the country fulfils three out the four economic criteria - price stability, public finances and long-term interest rate (European Commission 2018), it has been avoiding to accomplish the fourth criteria and participate on the Exchange Rate Mechanism (ERM II) based on the result of a national referendum held in 2003, in which 55.9\% of the Swedish population rejected the membership in the Eurozone (Stegmann McCallion 2018). To some extent, the Swedish example illustrates the limits in proposing neat categories to understand the relationship between Member States and the EU integration process.

Finally, the third, external differentiated integration, refers to agreements that some non-EU Members have, through which they take part in some communitarian policies. Although those agreements may represent the boundaries of States in terms of their willingness or eligibility to be institutionally entangled with the EU, they may also be 
understood as formal settlements of deeper interstate cooperation as the countries participate in some European policies. For example, the European Economic Area (EEA) includes Iceland, Liechtenstein and Norway in the EU's Single Market, while Turkey has a Customs Union with the EU. Each of these bilateral relationships with the EU project is very distinct and not all these countries seek membership. Iceland applied for EU membership in 2009; however, after a new government took office in 2013, accession talks were put on hold, and later, in 2015, the country withdrew its application. Norway, in turn, refused EU membership twice via referendums held in 1972 and 1994. Additionally, whereas Turkey applied for the then-ECC in 1987, being declared an eligible candidate in 1997, accession negotiations began only in 2005 and have recently been frozen (European Union 2019).

Similarly, the lower-left quadrant represents the three possibilities of differentiated disintegration. Firstly, internal differentiated disintegration concerns setbacks from a specific EU Member State in relation to the acquired integration. The 'special status' offered to the United Kingdom during the February 2016 negotiations of the European Council is an example, as will be explained in the next section. Moreover, if Greece had left the Eurozone after the 2008 financial crisis and returned to its currency, it would also be a case of disintegration, as the country was already part of this European policy.

Secondly, internal to external differentiated disintegration corresponds to secession negotiations in case a Member State decides to leave the European Union, as provided for in Article 50 of the Treaty of Lisbon, which came into force on 1 December 2009. The absence of a legal provision for the voluntary exit of a Member State from the European Union was not necessarily an impediment to this decision before 2009; however, it was through the Treaty of Lisbon that a procedure was formally established. Differentiated disintegration means that, according to Article 50 (Treaty of Lisbon 2009), the Union and the leaving Member State should negotiate a specific agreement to set the withdrawal arrangements between them. There is no standard agreement to be applied for exiting Member States.

Thirdly, external differentiated disintegration represents agreements to set a new relationship between the EU and the former EU Member State. Such case must be conceived as an external differentiated disintegration - and not integration - because it consists of a downgrading both in the level of centralization and the size of the membership of the European policies compared to the previous relationship. As mentioned earlier, disintegration is a relative position and not a specific outcome. Since 31 January 2020, the UK is no longer a Member of the EU. The UK and the EU set a transitional period until 31 December 2020, during which the country will not hold a seat in the EU institutions but still applies its communitarian rules. During this period, they must negotiate a new arrangement to set the terms of their future relationship.

Finally, the lower-right quadrant comprises possible general setbacks to the current status of EU integration. It is important to reinforce that it does not mean stagnation, but rather a return to an earlier stage of the already consolidated integration process. Although a uniformity disintegration has never occurred in the European process, the 
European Commission (2017c) considers it as an alternative scenario in its White Paper on the Future of Europe.

The following table sums up the proposed categorization based on the analysis of the second and third quadrants of Schimmelfennig's framework (2018a). It is the main contribution of this paper. The next section maps the current UK-EU developments with the help of this scheme.

Table 1 - Types of differentiated (dis)integration

\begin{tabular}{|c|c|c|c|}
\hline & $\begin{array}{l}\text { Type of differentiated } \\
\text { (dis)integration }\end{array}$ & Relation with EU & Context of (dis)integration \\
\hline \multirow{3}{*}{ 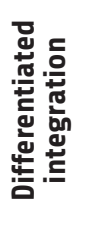 } & external & Non-EU Member & External Governance \\
\hline & external to internal & Future EU Member & Enlargement \\
\hline & internal & EU Member & Deepening \\
\hline \multirow{3}{*}{ 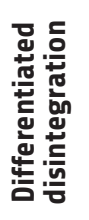 } & internal & EU Member & Shallowing \\
\hline & internal to external & Future former EU Member & Shrinkage \\
\hline & external & Former EU Member & External Governance \\
\hline
\end{tabular}

Source: Created by the author.

For this categorization of differentiated (dis)integration, the relationship between each State and the European Union is considered. It does not correspond to interpretations about the whole process of (dis)integration of the European project. As per Rosamond (2019: 37) 'even if we can specify particular phenomena as disintegrative, in so doing we do not necessarily specify an overall system-level consequence.' Besides, the proposed categorization aims to explain the differentiated (dis)integration in the EU primary law, meaning within the legal framework of EU treaties, and does not comprise the secondary $\mathrm{law}^{8}$ - the legal instruments based on these treaties, such as the Enhanced Cooperation procedure.

Moreover, these categories reflect formal institutional arrangements in the EU framework, not processes of (de)Europeanisation, which are also considered by part of the literature as differentiation and/or disintegration (Rosamond 2019). According to Chopin and Lequesne (2016: 536), ' [t] he various forms of differentiation should not, though, be confused with the rhetoric used in national political discourses to describe the politics of differentiation.' Whilst the politics of differentiation are related to the application, adaptation and incorporation of European policies into each national context, the types of 
differentiation proposed here correspond to the institutional achievements via official negotiations between the States and the EU institutions.

This paper proposes a comparative interpretation of these differentiated integration and disintegration types in order to understand the recent shifts in the UK's relationship with the EU in the next section to then discuss the effect of these changes to the (dis)integrative dynamic of the EU project.

\section{Brexit and the UK-EU relationship in the (Dis)Integration Framework}

As Ben Rosamond (2016: 865) argued, 'what Brexit might mean for both the UK and the EU has very quickly become the defining question of contemporary European politics.' Besides the historical British exceptionalism and its domestic factors that influenced the 2016 referendum outcome, Euroscepticism is widespread across Europe, fostering studies about European disintegration (Vollaard 2014). Scholars working with the EU are still trying to grasp analytically the (dis)integrative mechanisms unleashed by Brexit. This section aims to understand the recent transformation in the UK-EU relationship based on the proposed differentiated (dis)integration categories.

Indeed, Brexit represents an unprecedented break in a 40-year enlargement process of European Communities that expanded from the six founding countries to $28 \mathrm{mem}$ bers. It is the first time a Member State chose democratically via a referendum to divorce from the European Union following the procedure stated in Article 50 from the Lisbon Treaty. After two failed attempts to join the European Communities in the 1960's, the UK's decision to apply again for a membership was more a result of a utilitarian calculation considering the economic benefits of the Single Market and its geopolitical position in the international arena than a full acceptance of the political intentions of European integration (Schnapper 2017).

All in all, the UK enjoyed the best of both worlds by benefiting from opt-outs concerning certain policies, while also being a member with voice and right to vote inside the EU. In other words, the UK was able to enjoy the cooperation in many fields of its interest without getting involved or constrained in other areas, such as monetary policy. The British government has chosen to keep its mainly intergovernmental approach, particularly regarding sensitive issues. Due to this behaviour, the UK was considered an 'awkward partner' (George 1998). At the same time, the country made important contributions to EU construction, acting as a key driver for economic integration. The British approach also shaped a more intergovernmental Europe in some aspects, advocating for increasing powers for the European Council to the detriment of those for the European Commission.

Even though all this complexity ${ }^{9}$ of the UK-EU relationship may not exactly fit in neat categories, the proposed types of differentiated (dis)integration help to understand, in overall terms, the sequential process of UK disintegration unleashed since 2015. Throughout the Brexit process, the United Kingdom is moving from an internal differentiated integration with several opt-outs to an external differentiated disintegration. In sum, UK is passing from the second to the third quadrant of Figure 1. It is not the purpose of 
this paper to investigate the long- and short-term conditions that led to this 'perfect Brexit storm, but rather to illustrate, theoretically, UK-EU relationship movements towards disintegration since 2015 .

Before calling the in-out referendum, the Conservative Party strategy led by David Cameron was to renegotiate the terms of UK's membership in the European Union, demanding more flexibility and some exemptions from the communitarian obligations. Both the well-known Bloomberg speech in 2013 (Cameron 2013) and the 2015 Conservative Party manifesto draw a scheme based on reform, renegotiation and referendum. In accordance with the later, 'we will negotiate a new settlement for Britain in Europe, and then ask the British people whether they want to stay in the EU on this reformed basis or leave' (Conservative Party 2015: 72).

Cameron's proposal was to negotiate a more flexible, more competitive and more open European Union, in which the ambitions of the Member States could be widely met (Cameron 2013). For the then Prime Minister, British interests would be better addressed within a reformed European Union and not outside it; however, it was the promise of holding a referendum on the EU membership that actually underlay the Conservatives' campaign (Liddle 2016).

After his victory in the 2015 United Kingdom's general elections, Cameron immediately initiated talks with the then European Council president, Donald Tusk, to whom he addressed a letter in November 2015, asking for a reiteration of the British opt-outs and a moderate expansion of UK's differentiation (Schimmelfennig 2018a). In fact, at that time, besides its current status of internal differentiated integration, Britain was also looking for some internal differentiated disintegration, meaning a 'selective reduction of a state's level and scope of integration' (Schimmelfennig 2018a: 1), but not of its membership yet.

But why is it not an internal differentiated integration (traditional opt-outs)? In those cases, as integration progressed, some states decided to stay out of the achieved advances but not to return to an earlier stage of integration that had already taken place. The renegotiation of the UK's status inside the EU represents an internal differentiated disintegration because it proposed some specific setbacks concerning the integration patterns already achieved. In those UK-EU negotiations, a unanimous decision to concede a new special status to the UK inside the EU was reached.

On 19 February 2016, following a series of negotiations, European leaders jointly with the United Kingdom agreed on strengthening the country's special status within the bloc in an attempt to prevent its exit. In that sense, the conclusions of the European Council reaffirmed the differentiated position of the United Kingdom within the European Union by recalling that the country had the following rights, as agreed in the treaties and in the protocols to the Treaty of Lisbon: a. not to adopt the Euro, maintaining its national currency, the Pound sterling (Protocol No. 15); b. to exercise control of borders and, therefore, not to participate in the Schengen area (Protocols No. 19 and 20); c. to choose whether or not to participate in Community measures in the Area of Freedom, Security and Justice (Protocol No. 21); and d. not to be bound by the jurisdictional capacity of the Charter of Fundamental Rights of the European Union (Protocol No.30) (European Council 2016a). 
The conclusions of the European Council at that time reinforced the differentiated integration of the UK, particularly in areas identified as critical for the country, such as monetary policy and border control, while also providing some room for a differentiated disintegration. The European Council's decisions were published with four annexed declarations from the European Commission ${ }^{10}$ (European Council 2016). Furthermore, the text states that the content of these decisions should be incorporated into the next revision of treaties and the prerogatives of other European institutions should be respected. Overall, the European Council jointly with the European Commission has sought to meet British demands in the four areas appointed as priorities: 1. economic governance; 2 . competitiveness; 3 . sovereignty; and 4 . social benefits and free movement.

With regard to economic governance, it was agreed that 'Member States not participating in the further deepening of the economic and monetary union will not create obstacles to but facilitate such further deepening while this process will, conversely, respect the rights and competences of the non-participating Member States' (European Council 2016: 12). Considering that trade and economy comprise one supranational area under the responsibility of the Commission, the document recalls that the Union institutions must work together with the Member States to facilitate the coexistence between different perspectives. Also, emergency and crisis measures to ensure the financial stability of the Eurozone would not entail budgetary responsibility for countries that do not adopt the Euro as currency.

Concerning competitiveness, the European Council affirmed its commitment to 'lowering administrative burdens and compliance costs [...], while continuing to ensure high standards of consumer, employee, health and environmental protection' (European Council 2016: 15). The EU would, in addition, pursue an ambitious trade policy and improve its regulatory mechanisms. Attached to the European Council's conclusions, a Declaration on Competitiveness was released.

In relation to sovereignty, the most contentious issue, the agreement reached during the February 2016 negotiations provided the possibility of amendments to EU treaties to make clear that the intention of member countries to seek 'an ever-closer union', in accordance with the principle expressed at the Treaties of Rome in 1957, would not apply to the United Kingdom.

It is recognized that the United Kingdom, in the light of specific situation it has under the Treaties, is not committed to further political integration into the European Union [...] The competences conferred by the Member States on the Union can be modified, whether to increase or reduce them, only through a revision of the Treaties with the agreement of all Member States (European Council 2016: 16-17).

This exemption may be interpreted as a differentiated disintegration because it represents a setback to the well-known established principle from the Treaty of Rome to pursue 'an ever-closer union,' which is part of the acquis communautaire and implies a further 
political integration. As the United Kingdom was not a Member State of the European Communities in 1957, no opt-out to this compromise was negotiated at that time. The conclusion of the European Council in February 2016 not only conceded this special status to the United Kingdom; it also indicates that the next EU treaty revisions would explicitly include this exemption. In this sense, the European Council decision anticipated the need to modify EU primary law to allow a differentiated disintegration to the UK if the country decided to remain in the EU.

With regard to social benefits and free movement, the European Council agreed that the Member States have the right to define the fundamental principles of their social security systems and have relative discretion in implementing the conditions to access the benefits, allowing modifications towards a differentiated disintegration:

[T]he European Commission will table a proposal to amend Regulation 492/2011 on freedom of movement for workers within the Union to provide for a safeguard mechanism with the understanding that it can and will be used and therefore will act as a solution to the United Kingdom's concerns about the exceptional inflow of workers from elsewhere in the European Union that it has seen over the last years (European Council 2016: 34).

The justification for adopting such flexibility recalls the fact that the United Kingdom did not use the transition periods for free movement of people at the time of the Eastern enlargements. According to the European Council's conclusions, the UK faces an exceptional situation that requires the implementation of a safeguard mechanism to deal with the sharp inflow of workers in the country. This decision reiterates a process of differentiated disintegration of the United Kingdom during the February 2016 negotiations, because it represents a specific setback to an already achieved integration.

Besides the generic tone adopted throughout the text, which enables an interpretation that those exemptions or reformulations would be possible to apply to all EU Member States, section E, 'Application and Final Provisions', reaffirms that the consequences of these decisions by the European Council would take effect from the date on which the UK government reported the decision to remain a member of the European Union (European Council 2016). On 20 February 2016, the day after the closure of negotiations, the then Prime Minister David Cameron announced that the British referendum would be held on 23 June that same year. Following the referendum results, these decisions lost their effect. Moreover, the European Council decisions, titled 'Meeting within the European Council, concerning a new settlement for the United Kingdom within the European Union,' is clearly a negotiation of concessions to establish a new arrangement or a special status for the UK, even promoting some differentiated disintegration, in order to avoid its departure from the European Union.

In a nutshell, the UK-EU negotiations of February 2016 were an attempt to accommodate British demands inside the EU institutional framework by reinforcing its internal differentiated integration and also moving towards an internal differentiated disintegration 
in some aspects, aiming to prevent an external differentiated disintegration demand, such as Brexit.

Disintegration can lead to internal differentiation if a member state remains in the EU but exits from specific policies, or external differentiation if it exits from the EU but continues to participate in selected EU policies. After Cameron's re-election in 2015, he first negotiated to consolidate and expand the UK's exemptions from EU policies as a member state; after the Brexit referendum of 23 June 2016, negotiations shifted to external differentiation (Schimmelfennig 2018a: 1).

Figure 2 shows the shifts in the UK-EU relationship since the 2015 general elections. UK's opt-out to the EU legislation corresponds to a process of internal differentiated integration. After the February 2016 negotiations between the EU and the United Kingdom, the special status of internal differentiated disintegration, including an exemption to the principle of 'an ever-closer union,' would be granted once the UK had confirmed its wish to stay in the Union. However, following the British referendum outcome, the UK moved to a process of external differentiated disintegration.

Figure 2 - UK-EU relationship shifts since the 2015 general elections

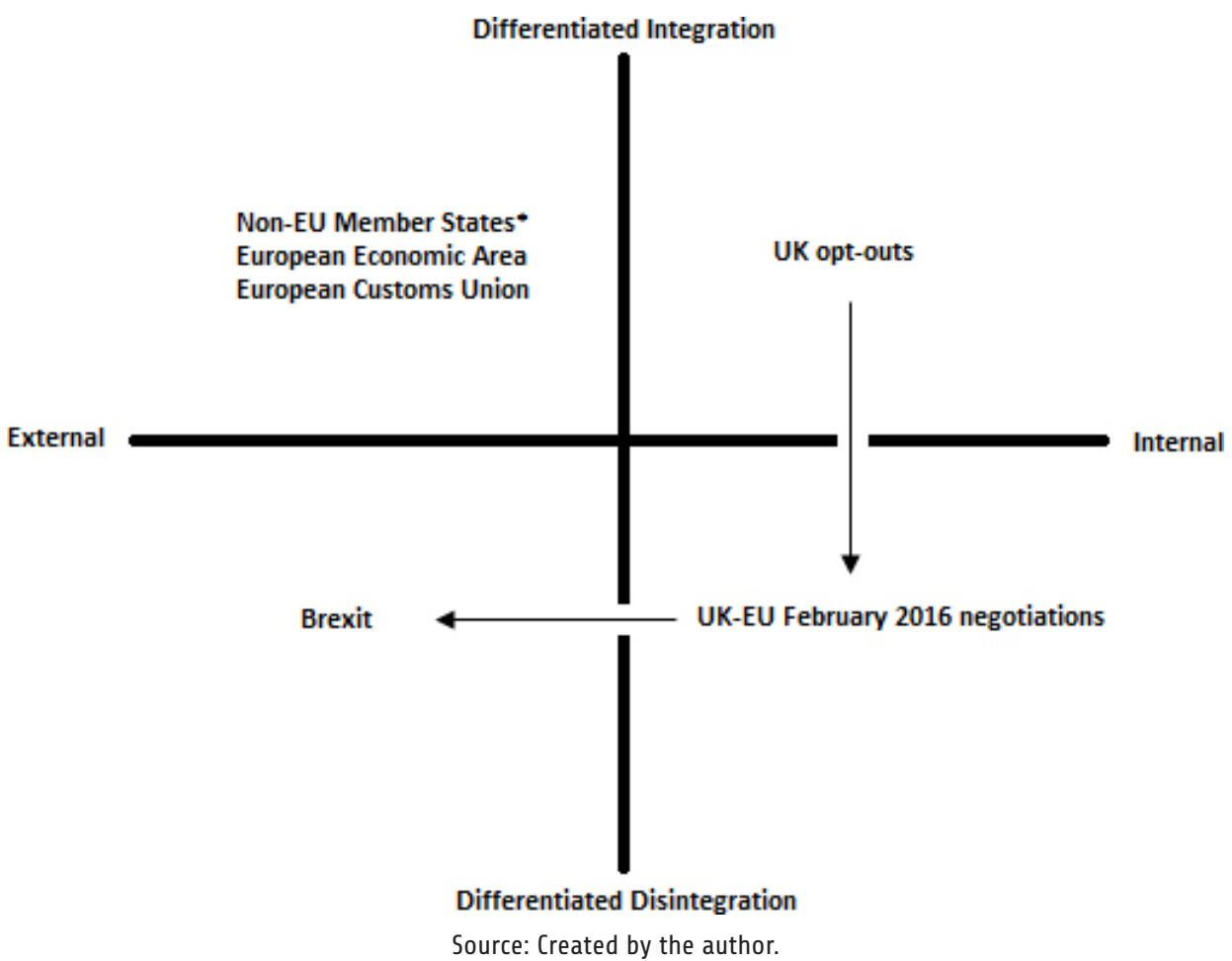


According to the procedure established by the European Commission (2017), once the United Kingdom triggered Article 50 of the Lisbon Treaty, the negotiations would consist of two phases. The first aimed at setting a Withdrawal Agreement between the UK and the EU; the second, at agreeing on the terms of a future relationship among them. In this sense, we could build a parallel of the differentiated disintegration with the three different types of differentiated integration. The UK-EU February 2016 negotiations would correspond to a process of internal differentiated disintegration as the UK - if it had decided to stay in the EU - would still be an EU Member with all rights and duties, but granted with a special status allowing some specific setbacks to the already achieved integration, as explained above.

The negotiation of a Withdrawal Agreement can be categorized as secession talks, in which the UK was still an EU Member, but would sooner become a former EU Member; contrary to accession talks, this process would correspond to the transition from internal to external differentiated disintegration. The EU has been concerned to start the second phase of negotiations without achieving sufficient progress in the first one towards a satisfactory arrangement for an orderly withdrawal (European Commission 2017a). It had only drafted a Political Declaration to express its aim for the future relationship, yet refused to go further on this discussion before the Withdrawal Agreement was signed and ratified both by the UK and the Union itself.

This final negotiation phase to set a new kind of UK-EU relationship represents the external differentiated disintegration, since, as a former EU Member State, the UK would have a different status from the others non-EU Member States. In its withdrawal process, the UK repealed the European Communities Act from 1972 and copied thousands of pieces from the acquis communautaire into the national legislation in order to avoid a legal vacuum in some areas that are predominantly regulated by EU laws. Moreover, both the $\mathrm{EU}$ and the UK declared their intentions to a closer cooperation in specific sectors, such as security and the fight against terrorism and transnational crimes.

The upper-left quadrant of Figure 2 corresponds to the Association Agreements that the EU has with non-EU Members, such as the EEA and the European Customs Union. Those are examples of external differentiated integration when non-EU states search for more cooperation with the Community without becoming an official EU Member. In those cases, there is an increase in the level of centralization, scope and membership regarding some EU policies. Indeed, internal differentiation is differentiation among member states of the EU, whereas external differentiation refers to the selective participation of non-members in the EU's integrated policies (as in the European Economic Area)' (Schimmelfennig 2018a: 3). Once again, we are here considering integration and disintegration as relative positions when compared to the previous relationship that each country - non-EU Member or former EU Member - had with the EU.

Regarding internal differentiated disintegration, the decision to grant a special status to the United Kingdom could open the door to litigation, as it would turn into a 'European Union à la carte,' with the risk that other countries would request exceptions to common rules in order to accommodate national interests, which may unravel either disintegrative 
dynamics to the EU or a reform of its integration project. The next section presents a brief analysis of the (dis)integrative effects of Brexit to the EU project.

\section{Brexit (dis)integrative dynamics to the EU project}

According to Schimmelfennig (2018b: 969), '[c] rises are open decision-making situations [...and] present a manifest threat and a perceived significant probability of disintegration, but may also trigger reform activities leading to more integration.' In this vein, Brexit represents a unique opportunity for a rethinking of the EU. From the UK's point of view, Brexit symbolizes a process of disintegration; however, its impacts on the European project can be contradictory, fuelling both integrative and disintegrating forces that can shape the course of the European Union in the coming years.

Be it for economic, migratory or political-ideological reasons, Euroscepticism has been gaining ground in several Member States of the European Union which can directly influence the future of the regional integration. Brexit is just an example. In that sense, besides the EU crisis, there has been a movement by the European institutions, especially the European Commission, to rethink the priorities of the integration process and reformulate the European project. Within this movement, we highlight some initiatives such as the presentation of the European Union's Global Strategy in June 2016, which gathers the principles that should guide EU Foreign Policy; the publication of the White Paper on the Future of Europe in March 2017, part of the European Commission's effort to outline possible scenarios for the EU27; the commemorations of the $60^{\text {th }}$ anniversary of the Treaties of Rome that opened a discussion on the course of the European Union; and the promotion of debates in the European Parliament during 2018 and 2019, with the leaders of the Member States on the need for reforms in the Community.

Considering the official documents of the European Union between 2016 and 2018, it is possible to identify the pillars of the proposals for the rebuilding of the European project. In short, the reformulation of European integration can be analysed from an external perspective of consolidating its position in the international system and redefining its political priorities, as well as an internal reorganization regarding the Community grounds that underpin the bloc and its institutional adaptation to the United Kingdom's withdrawal.

With respect to external aspects, the Lisbon Treaty, which entered into force in 2009, created the European External Action Service (EEAS), which functions as an EU diplomatic corps. Thus, the European Union's foreign policy gained more delineated trajectories and began to act jointly with the Member States, representing their interests in various themes (Costa 2017). Also, the EU Global Strategy (European Union 2016), drafted on the basis of European Council's guidelines and released on 28 June 2016, sought to clarify the primary interests of the regional bloc in terms of strategic security, such as the protection of its citizens and its territory, the promotion of prosperity and democracy, and the construction of a rule-based global order. 
Concerning the reorganization of the European Union with the departure of the UK following the outcome of the British referendum, there have been movements towards rapprochement and reiteration of European ideals by the other 27 Member States. On 29 June 2016, three days after the referendum, an informal EU27 meeting was held under the leadership of European Council President Donald Tusk. Apart from acknowledging the outcome of the British vote, the meeting reaffirmed the countries' commitment to remain united and not to engage in discussion with the United Kingdom until the British Government submitted the official formalization of the withdrawal, since the two-year negotiating period would only begin after formal communication of the decision to leave the EU, as set in Article 50 of the Treaty of Lisbon.

During the meeting, countries also recognized the need for the European Union to do more for its citizens who were dissatisfied with Community policies, as Donald Tusk's speech expressed: 'We also discussed the fact that there are too many people in Europe who are unhappy with the current state of affairs and who expect us to do better. [...] This is why we have started a political reflection on the future of the EU with 27 states' (European Council 2016b: n.p.). In this sense, this first meeting served as a basis for reiterating the commitment of the 27 Member States to redesign the European project aiming to avoid further disintegration inside the EU.

Similarly, in September 2016, the President of the European Commission, JeanClaude Juncker, reinforced his concern regarding the direction of regional integration in the State of the Union speech: 'Let us all be very honest in our diagnosis. Our European Union is, at least in part, in an existential crisis' (European Commission 2016: 6). For this reason, on the same occasion, Juncker proposed a positive agenda anchored in the reflection on the future of the European Union:

Yes, we need a vision for the long term. And the Commission will set out such a vision for the future in a White Paper in March 2017, in time for the 60th anniversary of the Treaties of Rome. We will address how to strengthen and reform our economic and monetary union (EMU). And we will also take into account the political and democratic challenges our Union of 27 will be facing in the future (European Commission 2016: 8).

Until then, the UK had not formalized yet its withdrawal request, but the European Union sought to consolidate itself as a cohesive bloc to deal with future challenges, hence the prompt reaction of the EU institutions to Brexit was to reinforce some integrative dynamics among the 27. In January 2017, in a letter to the heads of state and government before the informal meeting in Malta, Tusk stated that the threats faced by the EU at that time were far greater than those at the time of the Treaties of Rome. This threat narrative was another resource used to try to forge a larger internal unit.

The President of the European Council identified three main areas of concern. The first one, of external origin, consists of the new geopolitical situation of the international system, with the consolidation of a more assertive China, the strengthening of Russia, 
the continuous conflicts in Africa and the Middle East, the proliferation of terrorism and the unpredictability of the US government under Donald Trump's leadership. The second one, predominantly of internal origin, is characterized by the emergence of nationalist, Eurosceptic and/or xenophobic movements in several Member States of the European Union. Finally, the third, also of internal basis, includes the disbelief of the pro-European elites in the political integration of the Community and also in the defence of democratic liberal values (European Council 2017).

While the first threats could function as centripetal forces for integration, by forging the need to collectively strengthen the EU in dealing with the instabilities arising from the international conjuncture; the second ones can effectively be seen as centrifugal forces, favouring disintegrating tendencies. Finally, the role that European elites - both officials of the EU and of Member States' government authorities - will play could be decisive in the reformulation of the European Community project, with proposals varying within a spectrum from broad to narrow institutional and political integration, as published in the White Paper on the Future of Europe.

Donald Tusk's recommendation reiterated the commitment to the principle of seeking to consolidate an ever-closer union among the Member States at the commemorative events for the $60^{\text {th }}$ anniversary of the Treaties of Rome:

In Rome, we should strongly reiterate these two basic, yet forgotten, truths: firstly, we have united in order to avoid another historic catastrophe, and secondly, that the times of European unity have been the best times in all of Europe's centuries-long history. It must be made crystal clear that the disintegration of the European Union will not lead to the restoration of some mythical, full sovereignty of its member states, but to their real and factual dependence on the great superpowers: the United States, Russia and China. Only together can we be fully independent. [...] United we stand, divided we fall (European Council 2017: n.p.).

Indeed, in terms of Brexit's immediate effects to the EU project, the fear of a disintegrative domino effect was not confirmed. Since the Brexit repercussions, radical Eurosceptic demands for new departures were cooled down even among the most anti-EU parties. A new direction was taken aiming to reform the $\mathrm{EU}$ from the inside instead of leaving it. Equally, Eurobarometer surveys have shown an increase in support for European integration since 2016. Between 2018 and 2019, 68\% of the EU citizens found their country's EU membership beneficial, reaching its highest level since 1983 (European Parliament 2019: 17). Moreover, during the whole Brexit negotiation process, the EU27 has behaved as a relatively cohesive and united bloc despite the existing internal divergences ${ }^{11}$ (Lehmann 2018).

In spite of the integrative efforts of the EU institutions with the above-mentioned actions that seek to strengthen European unity, there is no deeper understanding of the disintegrative forces that still persist within the Member States. Moreover, in order to 
strengthen an external image of EU unity, some internal challenges to the integration process are underestimated, and attitudes that could correspond to disintegrating dynamics are neglected. For example, although the majority of respondents of the EU27 said that would vote in favour of remaining in the EU if their own country held a referendum on the subject, 12 of 27 countries registered an increasing number of respondents unsure about their decision and many of them believe that things are not going in the right direction, neither in the EU nor in their own country (European Parliament 2019: 20-25). In this vein, as pointed out by Pauline Schnapper (2019: 96):

Although the EU showed a high degree of resilience in the immedi-
ate aftermath of the Brexit vote, questions remain about the mid- to
long-term future of the European project and its underlying weak-
nesses. If the Brexit vote has not destroyed it, centrifugal forces
ranging from internal divisions and lack of solidarity to the rise of
'illiberalism' and populism continue to pose an existential challenge
to the Union.

According to Wodak (2019), there is a normalization process, in which the principles of European integration, understood as democracy, rule of law, respect for human rights, etc., are to some extent violated by the EU Member States, such as Hungary and Poland, without any ostensive reprimand from the EU institutions in a process that she calls the 'post-shameless era.' The rise of these illiberal forces combined with nationalist approaches may lead to disintegrative dynamics to the EU project. In sum, '[t]he non-compliance with EUropean [sic] values and the yearning for exceptionalism vehemently challenge the European project' (Wodak 2019: 208).

Moreover, some internal differences among the EU Members may hamper further integration, such as the opposition of the Visegrad Group, comprising Slovakia, Hungary, Poland and the Czech Republic, to Community proposals on migration policy. Another challenge envisaged in the State of the Union addressed both in 2017 and 2018 is the enlargement to the Western Balkans in the near future. Albania, Montenegro, North Macedonia and Serbia have already applied for EU Membership, while Bosnia and Herzegovina and Kosovo are potential candidates. Indeed, the Balkan region is crucial in terms of interdependence and cooperation with the EU, particularly in dealing with the migratory flow from Africa and the Middle East; however, their accessions may push even harder the differentiated (dis)integration inside the Union by increasing its heterogeneity.

Yet, the most worrying centrifugal forces are still hidden in the daily national practices that divert from the fundamental EU principles in a de-Europeanisation process. This means several misalignments to EU policies that might erode the EU project as we know it today. Those cases are not covered by the proposed categorization on this paper, which is restricted to formal differentiation arrangements in the EU's primary law, and as such, demands further investigation. 


\section{Conclusion}

The choice of the United Kingdom to leave the European Union along with the increase in nationalist and Eurosceptic movements across the continent contributed to the spread of an academic literature regarding disintegration. Integration and disintegration could not be understood as two binary outcomes of an interstate relationship. Indeed, both processes comprise a wide spectrum of interstate arrangements including dynamics of differentiation, regarding the level of centralization in different policy areas (vertical differentiation), and the number of participants (horizontal differentiation) (Leuffen, Rittberger and Schimmelfennig 2013).

The main argument of this paper is that the UK-EU relationship, especially in recent years, can be understood through the proposed categorization of types of differentiated (dis)integration. The United Kingdom already enjoyed an internal differentiated integration status due to its various opt-outs in relation to the Community legislation. Following Cameron's election in 2015, the UK sought to renegotiate its status within the bloc by aiming for a proposal for internal differentiated disintegration in agreement with the European Council in February 2016. However, based on the outcome of the referendum and after the triggering of Article 50 of the Lisbon Treaty, the United Kingdom has embarked on a transition process towards an internal to external differentiated disintegration, considering both the Withdrawal Agreement negotiations and a future relationship with the European Union.

Even though from the UK point of view Brexit means disintegration, its effects to the EU are mixed. Britain's departure pushed the EU to promote debates and reflections on the future of the Union in order to design the new course for the European project in the coming years to avoid new withdrawals. At the commemoration ceremony for the $60^{\text {th }}$ anniversary of the Treaties of Rome, Donald Tusk stressed that only a united Europe would represent a sovereign Europe capable of dealing with external and internal threats. In short, regardless of which alternatives there are for the future, the European institutions have been trying to reaffirm their commitment to the EU unity.

In the end, the departure of the United Kingdom directly affects the dynamics of European integration not only in terms of material capabilities, due to the need for institutional and budgetary readjustment, but also in its ideational pillars, through the revision of the principles and priorities that underpin the regional project. Previously, major EU studies and official documents of the European institutions have focused much more on alternatives towards further integration disregarding possibilities for disintegration. To some extent, the result of the British referendum brought a shock of pragmatism to European studies, as well as to the European Commission, which promptly started to consider disintegrating possibilities, as presented in the White Paper on the Future of Europe.

Indeed, European integration has never been homogeneous or uniform. The opt-outs, the transitional periods for accession countries or the agreements with non-EU Members have always been a form of differentiated integration that allowed communitarian advances both in terms of deepening and widening EU politics. Now, the EU has also to consider 
the prospect of differentiated disintegration paths, which may lead to the shallowing or shrinking of the acquis communautaire.

In short, although many issues remain to be solved, the tone adopted by the European institutions is still characterized by linear optimism based on the idea that in times of difficulty it is possible to forge deeper ties of integration. However, hopeful speeches in the EU should not hinder European studies from advancing on explanations about the disintegration process haunting the Community. This article joins the recent efforts in this area to investigate the (dis)integrative dynamics of Brexit to the European Union. Further studies will be necessary to improve the proposed analysis, for example, comparing British adherence to EU politics across time, particularly after its official withdrawal. Moreover, this study opens a brand new perspective regarding (dis)integration approaches and the possibility to apply it to other case studies, such as the South America integration at both MERCOSUR and UNASUR.

\section{Notes}

1 The acquis communautaire or EU's acquis is the body of common rights and obligations that are binding on all EU countries, as EU Members. See more at: https://eur-lex.europa.eu/summary/glossary/acquis.html

2 'Determined to lay the foundations of an ever-closer union among the peoples of Europe' (Treaty of Rome 1957).

3 The chaise vide crisis refers to the policy of blockage carried out by the French government under the presidency of Charles de Gaulle from 30 June 1965, to 30 January 1966, when De Gaulle suspended France's participation in the meetings of the Council of Ministers of the EEC, blocking the de facto decision-making process.

4 So far, only three territories of Member States have left the bloc: Algeria, when it gained independence from France in 1962; and Greenland and St. Bartholomew, which became overseas territories of the European Union in 1985 and 2012, respectively.

5 For example, one alternative for less integration in the White Paper is the second scenario called 'nothing but the single market' (European Commission 2017).

6 For further information on contestation see Wiener (2017).

7 On 22 October 2019, the European Commission reported on 'Croatia's progress in meeting the necessary conditions to join the Schengen area.' See more at: https://europa.eu/rapid/press-release_IP-19-6140_en.htm

8 For an analysis of differentiated integration in secondary law, see Duttle (2016).

9 For a complexity theory approach applied to EU integration, see Geyer (2003).

10 1. Declaration of the Commission on a subsidiarity implementation mechanism and a burden reduction implementation mechanism; 2. Declaration of the European Commission on the indexation of child benefits exported to a Member State other than that where the worker resides; 3. Declaration of the Commission on the safeguard mechanism; and 4. Declaration of the Commission on issues related to the abuse of the right of free movement of persons (European Council 2016: 32-36).

11 For an analysis of Brexit integrative effects to the EU, see Lehmann (2018).

\section{References}

Börzel, T A and T Risse. 2018. 'A Litmus Test for European Integration Theories: Explaining Crises and Comparing Regionalisms.' KFG Working Paper, 1-23. 
Cameron, D. 2013. EU speech at Bloomberg. At https://www.gov.uk/government/speeches/euspeech-at-bloomberg [Accessed: 25 October 2019].

Chopin, T and C Lequesne. 2016. 'Differentiation as a double-edged sword: Member states' practices and Brexit.' International Affairs 92 (3): 531-545.

Cianciara, A K. 2014. 'Differentiated Integration and the Future of Europe. Debate in Poland.' Yearbook of Polish European Studies 17: 167-189.

2015. 'Does Differentiation Lead to Disintegration? Insights from Theories of European Integration and Comparative Regionalism.' Yearbook of Polish European Studies 18: 39-58.

Cianciara, A K and A Szymański. 2019. 'Differentiated integration: towards a new model of European Union-Turkey relations?’ Turkish Studies 21 (2): 1-20.

Conservative Party. 2015. 'The Conservative Party Manifesto 2015. Strong Leadership, a Clear Economic Plan, a Brighter, More Secure Future.' At http://ucrel.lancs.ac.uk/wmatrix/ukmanifestos2015/localpdf/Conservatives.pdf [Accessed on 2 September 2020].

Costa, O. 2017. A União Europeia e sua política exterior (história, instituições e processo de tomada de decisão). Brasília: Fundação Alexandre de Gusmão.

Duttle, T, K Holzinger, T Malang, T Schäubli, F Schimmelfennig and T Winzen. 2016. 'Opting out from European Union legislation: the differentiation of secondary law.' Journal of European Public Policy 24 (3): 406-428.

European Commission. 2016. 'State of the Union 2016 by Jean-Claude Juncker, President of the European Commission.' 14 September. At https:/ec.europa.eu/commission/priorities/state-unionspeeches/state-union-2016_en [Accessed on 1 March 2019].

. 2017a. 'Special meeting of the European Council (Art. 50) (29 April 2017) - Guidelines.' At https://www.consilium.europa.eu/media/21763/29-euco-art50-guidelinesen.pdf [Accessed on 1 March 2019].

2017b. 'White Paper on the Future of Europe: reflections and scenarios for the EU27 by 2025.' At https://ec.europa.eu/commission/sites/beta-political/files/white_paper_on_the_future_of_europe_en.pdf [Accessed on 1 March 2019].

2018. 'The 2018 Convergence Report: Review of Member States' progress towards euro adoption.' At https://europa.eu/rapid/press-release_MEMO-18-3827_en.htm [Accessed on 1 March 2019].

European Council. 2016a. 'European Council meeting (18 and 19 February 2016) - Conclusions.' At https://www.consilium.europa.eu/media/21787/0216-euco-conclusions.pdf [Accessed on 1 March 2019].

2016b. 'Remarks by President Donald Tusk after the informal meeting of 27 EU heads of state or government.' At https://www.consilium.europa.eu/en/press/press-releases/2016/06/29/ tusk-remarks-informal-meeting-27/ [Accessed on 1 March 2019].

.2017. 'United we stand, divided we fall': letter by President Donald Tusk to the 27 EU heads of state or government on the future of the EU before the Malta summit. At https://www.consilium.europa.eu/en/press/press-releases/2017/01/31/tusk-letter-future-europe/ [Accessed on 1 March 2019].

European Parliament. 2019. 'Closer to the citizens, closer to the ballot. Eurobarometer Survey 91.1', Spring 2019. At https://www.europarl.europa.eu/at-your-service/files/be-heard/ 
eurobarometer/2019/closer-to-the-citizens-closer-to-the-ballot/report/en-eurobarometer-2019. pdf [Accessed on 3 March 2020].

European Union. 2016. 'Shared Vision, Common Action: A Stronger Europe. A Global Strategy for the European Union's Foreign and Security Policy.' At http://eeas.europa.eu/archives/docs/top_stories/pdf/eugs_review_web.pdf [Accessed on 13 November 2019].

2019. 'Countries.' At https://europa.eu/european-union/about-eu/countries_en [Accessed on 3 March 2020].

George, S. 1998. An Awkward Partner. 3rd edition. Oxford: Oxford University Press.

Geyer, Robert. 2003. 'European Integration, the Problem of Complexity and the Revision of Theory' Journal of Common Market Studies 41 (1): 1-33.

Holzinger, K and F Schimmelfennig. 2012. 'Differentiated Integration in the European Union: many concepts, sparse theory, few data.' Journal of European Public Policy 19 (2): 37-41.

Jones, E. 2018. 'Towards a theory of disintegration.' Journal of European Public Policy 25 (3): 440-451.

Lehmann, K E. 2018. 'Brexit as the Salvation of the European Union? Views from a Complexity Perspective.' In S L C Aguilar and I Z Alonso (eds), Os Desafios da Política Externa e Segurança no Século XXI. Marília: Oficina Universitária; São Paulo: Cultura Acadêmica, pp. 295-314.

Leruth, B, S Gänzle and J Trondal. 2019. 'Exploring Differentiated Disintegration in a Post-Brexit European Union.' Journal of Common Market Studies 57 (5): 1-18.

Leruth, B and C Lord. 2015. 'Differentiated integration in the European Union: a concept, a process, a system or a theory?' Journal of European Public Policy 22 (6): 1-10.

Leuffen, D, B Rittberger and F Schimmelfennig. 2013. Differentiated Integration: Explaining Variation in the European Union. New York: Palgrave Macmillan.

Liddle, R. 2016. The Risk of Brexit: the politics of a referendum. 2nd edition. Lanham: Rowman \& Littlefield.

Mahoney, J. 2001. 'Path-Dependent Explanations of Regime Change: Central America in Comparative Perspective.' Studies in Comparative International Development 36 (1): 111-143.

Rosamond, B. 2016. 'Brexit and the Problem of European Disintegration.' Journal of Contemporary European Research 12 (4): 864-871.

2019. 'Theorising the EU in crisis: de-Europeanisation as disintegration.' Global Discourse 9 (1): 31-44.

Schimmelfennig, F. 2016. 'Graded Membership in the European Union: Good Governance and Differentiated Integration.' KFG Working Paper Series.

. 2018a. 'Brexit: differentiated disintegration in the European Union', Journal of European Public Policy 25 (8): 1-20.

2018b. 'European integration (theory) in times of crisis. A comparison of the euro and Schengen crises.' Journal of European Public Policy 25 (7): 969-989.

Schimmelfennig, F, D Leuffen and B Rittberger. 2015. 'The European Union as a system of differentiated integration: interdependence, politicization and differentiation.' Journal of European Public Policy 22 (6): 1-18. 
Schnapper, P. 2017 'Brexit and the Risk of European Disintegration.' In N da C Cabral, J R Gonçalves and N C Rodrigues (eds), After Brexit: Consequences for the European Union. New York: Palgrave Macmillan, pp. 83-100.

Schuman, R. 1950. 'The Schuman Declaration - 9 May 1950, European Union.' At https://europa. eu/european-union/about-eu/symbols/europe-day/schuman-declaration_pt [Accessed on 3 March 2020].

Stegmann McCallion, M. 2018. 'Swedish Awkwardness à La Carte the difference a question mark can make.' In M Stegmann McCallion and A Brianson (eds), Nordic States and European Integration: Awkward Partners in the North? London: Palgrave, pp. 59-78.

Stubb, A. 1996. 'A Categorization of Differentiated Integration.' Journal of Common Market Studies 34 (2): 283-295.

Treaty of Lisbon. 2009. At http://publications.europa.eu/resource/cellar/688a7a98-3110-4ffe-a6b38972d8445325.0007.01/DOC_19 [Accessed on 1 March 2019].

Treaty of Rome. 1957. At https://ec.europa.eu/romania/sites/romania/files/tratatul_de_la_roma.pdf [Accessed on 1 March 2019].

Vollaard, H. 2014. 'Explaining European disintegration.' Journal of Common Market Studies 52 (5): $1-18$.

Webber, D. 2013. 'How likely is it that the European Union will disintegrate? A critical analysis of competing theoretical perspectives.' European Journal of International Relations 0 (0); 1-25.

Wiener, A. 2017. 'A theory of contestation - A concise summary of its argument and concepts.' Polity 49 (1): 109-125.

Winzen, T and F Schimmelfennig. 2016. 'Explaining differentiation in European Union treaties.' European Union Politics 17 (4): 616-637.

Zielonka, J. 2014. Is the EU Doomed? Cambridge: Polity Press.

Zürn, M. 2014. 'The politicization of world politics and its effects: Eight propositions.' European Political Science Review 6 (1): 47-71.

\section{About the author}

Angélica Szucko is a Ph.D. candidate in International Relations at the University of Brasília (UnB) with a scholarship supported by the Brazilian Federal Agency for Support and Evaluation of Graduate Education (CAPES) within the Ministry of Education of Brazil. Her research focuses on the UK-EU relationship and the paths that led to the Brexit process. She holds an MA in International Relations from the University of Brasília, Brazil. She did a Doctoral internship at Université Sorbonne Nouvelle, Paris 3, and worked as a temporary Professor of International Relations at the Federal University of Goiás (UFG) in 2017 and 2018. 


\section{Brexit e a (Des)Integração Europeia Diferenciada}

Resumo: Em 25 de março de 2017, a União Europeia comemorou o 60 aniversário dos Tratados de Roma, que estabeleceram 'uma união cada vez mais estreita' como um princípio fundamental para a integração regional. Apenas quatro dias depois, o Reino Unido entregou uma carta oficial que desencadeou seu processo de retirada da Comunidade. Como poderíamos compreender a dinâmica integrativa e desintegrativa do Brexit na UE? A decisão do Reino Unido de deixar a UE em meio às crises recentes na Comunidade e a disseminação de movimentos eurocéticos fomentaram estudos sobre a dinâmica da desintegração. Este artigo apresenta o debate atual sobre (des)integração diferenciada com base na literatura atualizada. Em seguida, propõe-se uma estrutura para avaliar as recentes mudanças nas relações Reino UnidoUE e seus efeitos contraditórios no projeto da UE. O principal argumento é que o relacionamento do Reino Unido com a União Europeia passou de uma integração diferenciada interna para uma proposta de desintegração diferenciada interna e, posteriormente, para um processo de desintegração diferenciada externa. Além disso, embora o Brexit signifique desintegração por parte de um Estado-Membro, seus efeitos no projeto da UE são mistos, promovendo inicialmente um boom integrador entre a UE27 e, ao mesmo tempo, negligenciando as forças de desintegração que poderiam minar o modelo tradicional de integração europeu.

Palavras-chave: União Europeia; Brexit; integração diferenciada; desintegração diferenciada; integração europeia.

Received on 16 August 2019, and approved for publication on 15 April 2020. 